\title{
10 Strengthening or weakening environmental institutions?
}

\author{
Chile and the establishment and \\ use of environmental courts in an \\ extractive economy
}

Violeta Rabi and Fernando Campos ${ }^{1}$

\section{Introduction}

The political assumption behind the resource curse or the paradox of plenty proposes that rent-seeking or windfalls in national economies dependent on the extraction and export of natural resources may have a detrimental effect on the robustness of existing regulatory institutions; the implementation and consolidation of institutional reforms; or even democratic quality in terms of transparency and participation (Auty, 1993). While research has confirmed these effects, this chapter aims to reinterpret the resource curse's political dimension (Brunnschweiler \& Bulte, 2008) and assess its applicability in cases that display a different institutional trajectory. To this end, our study explores the evolution and performance of the environmental institutions in Chile.

As an extractive economy, Chile's institutional evolution may suggest strengthening regulations, closer to what the ecological modernization theory proposes (Mol, 1997) or, as Bebbington (2010) states, a case where the extractive industry contributes to modernization and development. In fact, over the last three decades (1993-2019), Chile has experienced social processes that may even be regarded as counterintuitive if seen from a resource curse perspective. Parallel to the mining industry's highest growth and the copper price boom, there have been significant institutional changes seeking to improve environmental policy instruments' availability. Nevertheless, institutional strengthening has been put into question by implementing a market-enabling model rather than a market-regulation one (Tecklin et al., 2011) and by the lack of participatory institutions, similar to what has been seen in other Latin American countries (Falleti \& Riofrancos, 2018).

During the 1990s and 2000s, there was an unprecedented increase in foreign investment within the mining sector due to the return to democracy and the provision of legal stability to capital (Martínez \& Díaz, 1997). Though the price of copper was not exceptionally high, its contribution to GDP rose to about $10 \%$, even during complex economic contexts such as the 1998 Asian financial crisis. Likewise, the mining super-cycle saw an increase in copper's price from US $\$ 1$ /pound during the early 2000 s to a record high of US $\$ 4.6$ /pound in 2008 
(Álvarez et al., 2017). Thus, the price boom reinforced the extractive model and the idea that Chile can only achieve development as a mining country.

During the same period, the design and implementation of two major environmental reforms were executed. The official discourse proposed both of them as measures that would provide a clear set of rules for investors (Olivares, 2010; Guiloff, 2011).

The first transformation emerged as the result of the enactment of the Environmental Framework Act in 1994 and the entry into force of the Environmental Impact Assessment System (EIAS) as a mandatory step for the implementation of projects in 1997 (Moraga, 2010; Ulianova \& Estenssoro, 2012; Cordero et al., 2017). This reform was driven by the measures compelled in the 1992 Rio Convention. Hence, at the national level, international influence played a crucial role in the institutional transformations. The inclusion of compulsory public participation during the environmental impact assessment of particular projects, for instance, was a way to implement principle 10 of the Rio Convention, which demanded the right to public participation during decision-making processes conducted by the state. However, it was not until the second reform in 2010 that other aspects of this principle, such as access to information and environmental justice, came into play.

Global and subnational factors drove this second reform. On the international front, Chile's accession to the OECD meant reconsidering a series of recommendations laid out in an environmental report from 2005 that recommended strengthening the hierarchy of the environment sector at the state level (Sepúlveda \& Rojas, 2010; CNID, 2017). Locally, the collective pressure exerted by massive socio-environmental movements reflected the increasing public awareness about mega-project installation and its socio-environmental impacts (Pizarro, 2007; Sepúlveda \& Rojas, 2010). The most relevant cases were the protest against the construction of the Ralco hydroelectric plant in Mapuche territory in 1997, the Pascua Lama mining project in the Atacama Region and the pollution of a protected area of the Cruces River in Valdivia in 2004, and the emergence of national opposition to the construction of five hydroelectric plants in the Patagonia region as part of the Hydroaysén project in 2011.

As a result of the last reform, the Ministry of the Environment replaced the National Commission for the Environment (Comisión Nacional de Medio Ambiente, CONAMA). Additionally, three new agencies were created: The Superintendence of the Environment (Superintendencia de Medio Ambiente, SE), the Environmental Courts (ECs, Cortes Ambientales) and the Environmental Assessment Service (EAS, Servicio de Evaluación Ambiental). These entities were launched in 2012 (Cordero, 2010; Guiloff, 2010) to strengthen, oversee, and audit operations. The SE's function was to ensure compliance with existing environmental management instruments, while the ECs enabled citizens to challenge state decisions if they were deemed inappropriate.

Our research analyzes the operation of the ECs in Chile. Using these courts as a case study is highly relevant, as they may be understood from two opposite perspectives. On the one hand, they grant non-governmental actors access to 
environmental justice. On the other hand, the ECs offer project holders the possibility of challenging the state's environmental decisions. By analyzing the ECs' performance, we believe that the contradictions between the resource curse interpretations and the ecological modernization approaches may be explained. To this end, the ECs are explored at two levels: institutional design and implementation.

The results of this analysis suggest that institutional weakness and the sluggishness in the implementation of institutional reforms within extractive economies are not always directly related to the high income generated from the sale of natural resources but are somewhat due to more complex interactions between the performance of institutions and the social actors who use them. Indeed, institutional space may be regarded as a disputed territory whose dynamics may be addressed by the notion of institutional colonization, understood as social actors' capacity to influence institutional environments to introduce specific practices and ideas (Boltanski, 2012).

The chapter is divided into five sections. The introduction is followed by a theoretical framework where the resource curse and the ecological modernization institutional perspectives are presented. Afterwards, we develop the concept of institutional colonization for Chile, where a convergence exists between the export-oriented boom and institutional development. The third section briefly describes the method employed and the main characteristics of the ECs. The fourth section shows the results of the study. It is divided into four parts: the origin and institutional design of the ECs, the actors involved in the ECs, the cases heard in the ECs and the outcomes of the trials. The final section concludes and suggests further research possibilities.

\section{Chile: between the resource curse and ecological modernization perspectives}

There is a wealth of international literature on the paradox of plenty, which dates back to its emergence during the 1990s (Auty, 1993; Sachs et al., 1995). The analysis of these works reveals that efforts have been focused on explaining why the abundance of natural resources does not ensure countries' economic development (Ross, 2015). In this approach, regulatory institutions, which are theoretically in charge of mobilizing public resources from extractive activities to national development, become - in the best-case scenario-insufficient orin the worst-case scenario-corrupted (Olavarría, 2003). Likewise, this inability to transfer public funds for the benefit of the population is not reversed during times of prosperity; on the contrary, it becomes an even more acute problem. Therefore, the political dimension behind the paradox of plenty may predict institutional weakening episodes during commodity super-cycles since state bureaucracies have less incentive to regulate and adopt instead a laissez-faire approach.

On the other hand, and parallel to the research on the paradox of plenty, sociologists have been trying to make sense of the emergence of environmental 
institutions observed in industrial processes within developed economies (Jänicke, 2017, 2020). The ecological modernization theory predicts and promotes industrial and institutional transformation with a specific focus on environmental protection by linking investment and profits with cleaner industrial processes.

Even though the ecological modernization theory focuses on developed or post-industrial countries (Mol \& Sonnenfeld, 2014), it is difficult to argue that a theory that explicitly addresses modernization processes and socioenvironmental demands can be self-restricted to a small group of states and, therefore, to a small fraction of the world's population. In this sense, it is safe to say that most nations have transformed their institutional frameworks according to a sustainability approach, based on technological improvement, entrepreneurship promotion, and market-based solutions over the last three decades (Foladori, 2005). In this context, institutional transformation is triggered by the growing need and urgency to incorporate sustainable measures into production and consumption models. From an ecological modernization perspective, this means that companies and the states might reduce the negative impacts generated by their productive activities and benefit from impact reduction processes by putting adequate market incentives in place and participating in multilateral negotiations to improve environmental conditions worldwide, as part of the so-called international environmental governance (Buttel, 2003).

The utility of describing both theories is that they reveal two opposite evaluations of institutional performance. Chile presents a challenge to both understandings: its institutions have not been severely affected by the resource curse, and the two waves of institutional modernization (described in the introduction) have not been entirely oriented towards environmental protection.

Although the reforms of Chilean environmental institutions involved creating a series of procedures aimed at promoting public participation in investment decision-making processes and enabled access to environmental justice, the analysis of how these so-called technical procedures actually work inevitably leads us to a more critical position. Indeed, the same period in which environmental institutions have been reformed showed an unprecedented increase in extractive activities (Altieri \& Rojas, 1999), the rise of socio-environmental conflicts (Delamaza et al., 2017), and the extreme cases of socio-environmental impacts in sacrifice areas ${ }^{2}$ (Bolados \& Sánchez-Cuevas, 2017).

Therefore, it can be argued that current institutional transformations have not contributed to relieving pressure on the environment and local populations. Dramatic cases such as the ownership of water rights, which are controlled by powerful groups (Bauer, 2002; Larraín, 2007); the intensification of polluting activities in already degraded territories (Cortés et al., 2016); and questionable socio-environmental compensation methods in exchange for social consent (the so-called social license) to operate mega-projects (Chile Transparente, 2018) are all allowed and legitimized within the Chilean institutional setting. 
The previous may sound contradictory under the assumption that the lack, or weakening, of institutions is the main reason behind socio-environmental issues. However, our study argues that existing regulatory systems foster socio-environmental pressure on an important number of local communities and ecosystems. Therefore, institutional frameworks should be examined to explore the reasons behind the emergence of contemporary forms of socioenvironmental suffering (Auyero \& Swistun, 2008, 2013), which exist not only in the lack or weakening of regulatory institutions but also in their implementation. We propose to analyze this dynamic drawing on the concept of institutional colonization.

This concept describes how institutional designs, created for socially agreed purposes and in line with legally discussed procedures, are jeopardized or destabilized by specific groups who use them for their interests. In this sense, colonization processes should be explored in terms of institutional design and implementation.

Following this concept, the ECs cannot be immediately associated with institutional improvement due to greater access to environmental justice. On the contrary, we argue that the legal system cannot be regarded only as a guarantor of environmental justice. Instead, it can be understood as a space intended to legitimize socio-environmental tensions resulting from the multiple interests of different social groups. ECs provide a platform for catalyzing socio-environmental conflicts, and the concept of institutional colonization represents the struggles between different powers converging in this process. Hence, aspects such as the actors involved and the decisions issued by the ECs are elements that contribute to the analysis of the performance of these courts.

\section{Methodology}

The study is based on secondary information, systematized and analyzed to explore the emergence and operation of the ECs in Chile. The history of Acts No. 20.417 and $20.600^{3}$ enabled us to describe the social conditions under which the new institutional framework was designed. Furthermore, the analysis of legal cases considered by the ECs provided detailed information on who was involved in litigation and how the courts reached their decisions. This data was obtained from an inspection of electronic files on the ECs' website and recorded and organized in a qualitative database. ${ }^{4}$ Further information was obtained from state organizations through transparency requests.

ECs are specialized legal bodies mostly in charge of ruling on contentious administrative cases; they oversee compliance with normative procedures. Since, in terms of competence, legal claims are the center of ECs, our research will focus on them. Legal claims ${ }^{5}$ accounted for $77.3 \%$ of total cases (184) and triple the number of environmental damage claims. In this way, the resolution of contentious administrative issues was the subject of most of the 238 cases handled by the ECs (see Table 10.1). 
Table 10.1 Total cases processed by the environmental courts (ECs)

\begin{tabular}{llcr}
\hline Year & $\begin{array}{l}\text { Claims of } \\
\text { environmental } \\
\text { damage }\end{array}$ & Legal claims & Total \\
\hline 2013 & 7 & 20 & 27 \\
2014 & 10 & 46 & 56 \\
2015 & 15 & 45 & 60 \\
2016 & 22 & 73 & 95 \\
Total & $\mathbf{5 4}$ & $\mathbf{1 8 4}$ & $\mathbf{2 3 8}$ \\
\hline
\end{tabular}

Source: Database compiled by the authors with data from EC 2013-2016, available in the websites of the three courts: http://2ta.lexsoft.cl/2ta/search?proc $=4$ and https://causas.3ta.cl/.

Types of legal claims recognized by the ECs are listed as follows in Act No. 20.600: ${ }^{6}$

No. 1: Cases against executive orders establishing primary or secondary regulations on environmental quality and emission standards, declaring latent, or saturated areas and establishing prevention or decontamination plans (Article 17, subparagraph 1);

No. 3: Cases against resolutions issued by the Superintendence of the Environment if they do not comply with legislation, regulations or other relevant legal provisions, as well as against the imposition of fines (Article 17, subparagraph 3);

No. 5: Against resolutions rejecting or establishing conditions or requirements on Environmental Impact Statements (EISs) or Environmental Impact Assessments (EIAs) or rejecting review requests regarding Environmental Assessment Authorization (Resolución de Calificación Ambiental, RCA in Spanish) (Article 17, subparagraph 5);

No. 6: Against the fact of disregarding the observations made by citizens during the mandatory public participation process of the environmental impact assessment process (Article 17, subparagraph 6);

No. 7: Against administrative actions taken by ministries or public services regarding the enforcement or implementation of quality and emission standards and prevention and decontamination plans if they contradict the law, rules or objectives of the instruments mentioned above (Article 17, subparagraph 7); and

No. 8: Against resolutions determining the invalidation of environmental administrative procedures (Article 17, subparagraph 8).

For the study, the different users identified as claimants are:

I Project holders, which are divided into private companies, public companies and state bodies; 
II Indigenous communities;

III Civil society grassroots organizations, such as neighborhood councils, trade associations, and environmentalist organizations;

IV Persons who go to court either individually or collectively and do not fall into previous categories due to the temporary nature of their organizations, which are associated with specific interests;

$\mathrm{V}$ Companies that do not own disputed projects;

VI Democratically elected representatives, such as council officials, members of Congress and regional councilpersons.

\section{Results}

\section{Origins and operation of the ECs}

Initially, the ECs were not considered part of the 2010 environmental institutional reform. They emerged during parliamentary discussions when right-wing politicians expressed their distrust of the extensive vigilance and sanctioning powers of the new Superintendence. For various reasons, the idea of creating the ECs was endorsed by environmental NGOs, as they recognized the need to have adequate access to justice for socio-environmental issues. Therefore, to adopt Act No. 20.417, the executive and members of the parliament signed a memorandum of understanding to create a specialized environmental jurisdiction under the Supreme Court's direct control (Plumer, 2013).

In line with the previous, the Act No. 20.600 of 2012 created the ECs per the following four considerations: judicial control over decisions issued by environmental administrative authorities; control should be handled by specialist rather than generalist judges; these courts should be composed of expert staff in legal and technical areas; given their specialized and unique nature, these courts should issue predictable decisions, thus providing legal certainty for all parties involved.

Hence, the parliamentary negotiations acknowledged the idea that the powers of the ECs would not be restricted to addressing decisions issued by the Superintendence of Environment but also expanded to anything regulated by the Environmental Act (Act No. 19.300), which would allow access to environmental justice in a wide range of matters (Library of the Chilean National Congress, 2010). However, despite the expansion of the matters for which it is competent, the administrative litigation ECs' scope produces a bias towards procedural reviews. Indeed, the ECs focus on settling the legality of applying environmental management instruments, regulations and administrative actions associated with them. In other words, the primary role of the ECs is to assess whether authorities have infringed the procedures established by law, dealing with claims or objections regarding the legality of actions or sanctions emanating from the administration (Bermúdez, 2016). Unregulated natural elements by Act No. 19.300, such as land planning, water, or forest resources, do not fall within the domain of these courts. 
Furthermore, only a restricted category of actors can appeal to the ECs. In this respect, Moraga (2012) explains that the Act's final text was more restrictive than the original proposal. She argues that reasons for admission are always connected to specific actors. For example, only citizens who have participated in the public consultation during the environmental impact assessment can present a legal claim against the accuracy or sufficiency of the environmental assessment agency's response. The previously mentioned implies that citizens who did not have the chance to participate in this previous instance are prevented for this reason from using the court even if they consider that their interests have not been guaranteed.

In sum, the parliamentary negotiations review shows that the ECs were created for counterbalancing the powers granted to the SE. Ultimately, the final design of the ECs focused on the formal monitoring of procedures aimed at ensuring the regular operation of existing environmental management instruments-regulations, plans, environmental assessment-rather than on the provision of legal tools to ensure environmental protection as an end in itself. Additionally, the instruments addressed by the ECs explicitly restrain the array of actors who may use them in specific cases, limiting the access and type of environmental justice to one that is bounded and procedural.

\section{Who takes cases to ECs?}

This section analyzes which kind of parties have appealed to the ECs to resolve environmental controversies. The data shows that claims have been filed in the first place by private companies and natural persons (see Table 10.2). When taking the project holder category (adding private and public companies and state bodies) and the non-project holder category (the rest of the categories described in Table 10.2) as a whole, both turn to the courts to an equal extent, 92 cases each. Despite this, the positions of these two groups are not necessarily the same. In the case of project holders, they emerge as actors with the specific interest of ensuring implementation of their investment projects. This is not the case for the rest of the users since the non-project holder category encompasses different interests and positions.

While indigenous communities and environmental organizations aim at defending local territories and specific ecosystem and cultural conditions, grassroots organizations turn to courts for a variety of concerns, ranging from the protection of the environment or specific resources (such as water) to the protection of economic activities (as in the case of fishing associations). The non-project holder category also includes representatives from other than the project holder companies who are affected by the implementation of investments. This is the case, for instance, with agricultural companies filing claims against mining companies. Finally, it is challenging to identify natural persons' interests, ranging from ecological or quality of life concerns to economic interests.

Another form used to categorize the type of users is the distinction between organized civil society and non-organized civil society, which is based on identifying 
Table 10.2 Number of legal claims by type of user

\begin{tabular}{lcc}
\hline Type of user/type of action & Legal claims & Total \\
\hline Project Holder (Private Company) & 82 & $44.6 \%$ \\
Individuals & 37 & $20.1 \%$ \\
Grassroots Organization & 20 & $10.9 \%$ \\
Indigenous Community & 12 & $6.5 \%$ \\
City Council & 7 & $3.8 \%$ \\
Other Complaining Company & 7 & $3.8 \%$ \\
Project Holder (State Company) & 6 & $3.3 \%$ \\
Socio-Environmental Organization & 5 & $2.7 \%$ \\
Representative of Popular Election & 4 & $2.2 \%$ \\
Project Holder (State Body) & 4 & $2.2 \%$ \\
Total & $\mathbf{1 8 4}$ & $\mathbf{1 0 0 \%}$ \\
\hline
\end{tabular}

Source: Database compiled by the authors with data from EC 2013-2016 (references in Table 10.1).

Note: The total considers cases both closed and pending.

collective and individual claims. There are 37 claims filed by indigenous communities, grassroots organizations, and environmentalist organizations (accounting for $20 \%$ of total claims) against the 44 claims filed by natural persons and other complaining companies ( $24 \%$ of total claims). There are also claims filed by public authorities, representing $5 \%$ of the total claims (see Table 10.2).

The claims filed to the ECs can also be classified according to the projects' distribution among economic sectors. The majority of them are associated with three: mining, energy and water, sanitation and hygiene (WASH). These sectors represent $24 \%, 22 \%$, and $14 \%$ of the total number of cases filed, respectively, which accounts for $60 \%$ of the country's total legal claims (see Table 10.3). In the two first categories, claims were presented by holders and non-holders of projects. Claims regarding the WASH sector are filed mostly by project holders.

As a general tendency, claims are filed by project holders to allow continuation of their investments. This suggests that most of the claims filed in the ECs are not intended to stop the implementation of projects, but rather to go ahead with them. Claims filed in equal numbers by project holders and non-project holders were only seen in specific economic sectors, especially in the case of energy and mining mega-projects that, according to the literature, are the sectors most prone to the emergence of socio-environmental conflicts (INDH, 2015).

\section{Which cases are heard in the ECs?}

The law stipulates that cases handled by the ECs are limited by two considerations: they can only handle claims that fall under the reasons stipulated by article 17 of Act No. 20.600, and only those with legal standing authorized by law can participate in these legal proceedings. 
Table 10.3 Legal claims by type of user and economic sector

\begin{tabular}{|c|c|c|c|c|c|c|c|c|c|c|c|c|}
\hline $\begin{array}{l}\text { Type of user/economic } \\
\text { sector }\end{array}$ & $\begin{array}{l}\text { Agriculture and } \\
\text { Livestock }\end{array}$ & Energy & Forestry & Industry & Real Estate & Mining & $\begin{array}{l}\text { Public } \\
\text { Works }\end{array}$ & $\begin{array}{l}\text { Fish } \\
\text { Farming }\end{array}$ & $\begin{array}{l}\text { Land } \\
\text { Planning }\end{array}$ & WASH & Other & Total \\
\hline Indigenous Community & 0 & 3 & 3 & 0 & 0 & 4 & 0 & 2 & 0 & 0 & 0 & 12 \\
\hline Grassroots Organization & 1 & 6 & 0 & 1 & 5 & 4 & 0 & 1 & 2 & 0 & 0 & 20 \\
\hline $\begin{array}{l}\text { Social Environmental } \\
\text { Organization }\end{array}$ & 0 & 3 & 0 & 0 & 2 & 0 & 0 & 0 & 0 & 0 & 0 & 5 \\
\hline $\begin{array}{l}\text { Other Complaining } \\
\text { Company }\end{array}$ & 1 & 3 & 0 & 1 & 0 & 2 & 0 & 0 & 0 & 0 & 2 & 7 \\
\hline Natural Persons & 0 & 10 & 2 & 0 & 4 & 10 & 5 & 2 & 0 & 2 & 0 & 37 \\
\hline $\begin{array}{l}\text { Representative by } \\
\text { Popular Election }\end{array}$ & 0 & 2 & 0 & 0 & 0 & 0 & 0 & 0 & 0 & 1 & 1 & 4 \\
\hline $\begin{array}{l}\text { Project Holder (State } \\
\text { Company) }\end{array}$ & 0 & 0 & 0 & 0 & 0 & 2 & 4 & 0 & 0 & 0 & 0 & 6 \\
\hline $\begin{array}{l}\text { Project Holder (Private } \\
\text { Company) }\end{array}$ & 8 & 9 & 0 & 7 & 8 & 22 & 1 & 3 & 0 & 20 & 4 & 82 \\
\hline
\end{tabular}

Source: Database compiled by the authors with data from EC 2013-2016 (references in Table 10.1).

Note: The total considers cases both closed and pending. Category "Other" is cases related to general norms of emissions. 
We divided the claims filed into three categories: claimant profile, the institution that was the subject of the claim, and reason for admission established by law (see Table 10.4). In general terms, with 95 and 72 cases each, the Superintendence of the Environment (SE) and the Environmental Assessment Service (EAS) account for the most significant number of legal actions taken against public entities (51\% and 39\% of total claims, respectively). While project holders from private companies only filed claims against the SE, legal actions against the EAS were taken by project holders, grassroots organizations, and natural people.

Regarding the grounds for making claims, out of 179 cases, reasons related to review the decisions made by the Superintendence of the Environment, No. 3 (87 cases) stands out as the primary motive. These claims are filed mainly by project holders who request a revision of the interim measures or sanctions imposed on them. On the other hand, non-project holders focus their claims on complaints, approval of compliance plans, and, to a lesser extent, sanctions. Though both project holders and non-project holders file requests for sanctions, the latter used this procedure when there was disagreement regarding the magnitude of the fines imposed, such as on the Pascua Lama and Caserones mining projects and the Bocamina thermoelectric project, arguing that they were too low.

Reasons related to invalidation of the procedures (No. 8) are the secondmost-used motive in legal claims, concentrating 46 cases. Although there are 14 cases where project holders addressed invalidation, this reason is mainly used by natural persons and grassroots organizations when filing claims against the EAS (12 and 9 cases each, respectively). On aggregate, this reason is used mainly by non-project holders (67\% of total claims), of which 15 came from organized civil societies, 13 from non-organized civil societies, and four from local government representatives (regional councils or municipalities).

Reason No. 6 refers to claims based on the observation of flaws detected by citizens during the public participation process. All of these claims challenge environmental assessments favorable for the companies. It is worth highlighting that reason No. 6 is less frequently used than the invalidation No. 8 (32 cases vs. 15 cases), as the former requires the submission of observations during the stages of public participation. This conditioning factor restricts the broadening of access to environmental justice.

In the context of restrictive rules to access to ECs, our analysis suggests that invalidation is the primary tool used by civil society to prevent projects from being authorized. This instrument is used since it is the only possibility that allows users to take action about issues that have not been included in the environmental impact assessment. It is, therefore, safe to say that members of the civil society interested in using the ECs should base their claims on invalidation grounds, having to demonstrate the occurrence of illegality during the process. This may distort the type of cases handled by the ECs, as the institutional setting requires them to look for a normative breach to obtain access to the ECs.

Lastly, reason No. 5 refers to claims against unfavorable or the conditional approval of the environmental impact. It is not surprising that project holders 
Table 10.4 Legal claims by type of claimant, respondent, and reasons from Article 17, 2013-2016

\begin{tabular}{|c|c|c|c|c|c|c|c|c|c|}
\hline Claimant [respondent]/Article 17 & No. 1 & No. 3 & No. 5 & No. 6 & No. 7 & No. 8 & $N / E$ & Total & $\%$ \\
\hline EAS & 0 & 0 & 1 & 2 & 0 & 4 & 2 & 9 & $5 \%$ \\
\hline Municipality & 3 & 0 & 2 & 0 & 0 & 2 & 0 & 7 & $3.9 \%$ \\
\hline Ministry of the Environment & 3 & 0 & 0 & 0 & 0 & 0 & 0 & 3 & $1.7 \%$ \\
\hline EAS & 0 & 0 & 2 & 0 & 0 & 2 & 0 & 4 & $2.2 \%$ \\
\hline $\begin{array}{l}\text { Organ with Environmental } \\
\text { Competence }\end{array}$ & 0 & 0 & 0 & 0 & 0 & 1 & 0 & 1 & $0.5 \%$ \\
\hline EAS & 0 & 0 & 0 & 1 & 1 & 8 & 0 & 10 & $5.6 \%$ \\
\hline ES & 0 & 7 & 0 & 0 & 0 & 0 & 1 & 8 & $4.4 \%$ \\
\hline $\begin{array}{l}\text { Socio-Environmental } \\
\text { Organization }\end{array}$ & 0 & 1 & 0 & 2 & 0 & 2 & 0 & 5 & $2.6 \%$ \\
\hline EAS & 0 & 0 & 0 & 1 & 0 & 1 & 0 & 2 & $1.1 \%$ \\
\hline ES & 0 & 5 & 0 & 0 & 0 & 0 & 0 & 5 & $2.8 \%$ \\
\hline Natural Persons & 2 & 11 & 2 & 9 & 0 & 12 & 1 & 37 & $20.6 \%$ \\
\hline
\end{tabular}


Ministry of the Environment

2
0

Organ with Environmental

Competence

EAS

ES

Representative by Popular

Election

EAS

ES

Project Holder (State

Company)

Organ with Environmental

Competence

\section{EAS}

ES

Project Holder (Private

Company)

Ministry of the Environment

Organ with Environmental

Competence

EAS

ES

Project Holder (Organ of the

State)

EAS

Total

0
0

0

0

0

0

1
1

0
0

Source: Database compiled by the authors with data from EC 2013-2016 (references in Table 10.1).

Note: The total considers cases both closed and pending, five legal claims included under the scope of Act No. 20.473 have been excluded from the database.

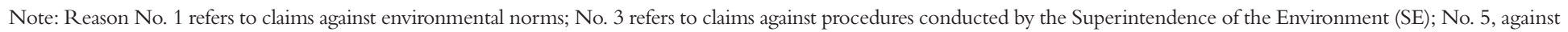

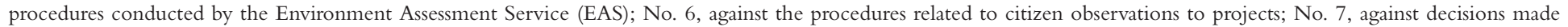
related to decontamination plans; and No. 8 refers to the general invalidation process. 
file almost all claims. However, this reason may also be used to request the revision of EIAs. In this case, claims may be filed by those directly affected by EIAs when the variables under assessment and monitoring have substantially changed once projects are already underway. In this last case, reason No. 5 is used to oppose investment projects. This has happened five times through claims filed by indigenous communities, local city councils and natural persons.

According to our results, there are restrictions in the institutional design of ECs that hamper access to justice for most communities. This problem becomes evident in our finding that organized communities represent only $21 \%$ of total claims. Likewise, only a limited number of complaints are filed by non-project holders against institutional entities for ignoring citizens' observations. As a whole, these cases and invalidation actions filed by the communities account for $26 \%$ of total claims. By contrast, claims presented by project holders represent $49 \%$ of total cases.

Most of the claims are filed by project holders, meaning that claims refer to projects already underway rather than projects under assessment. In this sense, the image being spread that civil society is halting projects through the use of the legal system is not entirely fair. The performance of the ECs shows that institutional rules privilege project holders to press their claims in court, while other citizens face several high barriers. The latter reinforces a structural asymmetry upheld by the institutional design, suggesting that the ECs are best understood as serving as a counterbalance to the SE.

\section{How do the ECs resolve disputes?}

In this section, we identify how the ECs resolved cases. From the 184 claims considered here, 141 were completed by the end of 2017 . Within this sample, 106 of these cases received a final judgment issued by the ECs. From this figure, 52 cases (49\% of total claims) concluded with a decision handed down by the ECs, and 54 cases (51\% of total claims) finalized with a ruling issued by the Supreme Court. This means more than half (54) of all cases completed in the ECs (106) were challenged by a cassation appeal, moving from a specialized court to a generalist one. Thirty-five cases concluded without a decision, most of them because they were deemed inadmissible by the court, or the claimants withdrew them.

At ECs, most of the 106 cases concluded were rejected (see Table 10.5); in other words, claimants lost at trial. This means that, regardless of the type of claimant, most of them received an unfavorable ruling. Out of the 69 claims rejected by the ECs, 38 were filed by project holders, and non-project holders filed 31 . As for the 18 claims approved by the ECs, both were filed equally by project holders and non-project holders.

It is worth noting that all claims made by indigenous communities, environmental social organizations and other complaining companies have been rejected. Regarding organized civil society, only two claims out of 18 were supported by the ECs; this contrasts with the nine claims won by project holders. 
Table 10.5 Claims by type of resolution

\begin{tabular}{|c|c|c|}
\hline Outcome of the cases in the ECs & Frequency & $\%$ \\
\hline Allowed & 18 & $16.8 \%$ \\
\hline Municipality & 2 & $11.1 \%$ \\
\hline Grassroots Organization & 2 & $11.1 \%$ \\
\hline Natural Persons & 5 & $27.8 \%$ \\
\hline $\begin{array}{l}\text { Project Holder-State } \\
\text { Company }\end{array}$ & 1 & $5.6 \%$ \\
\hline $\begin{array}{l}\text { Project Holder-Private } \\
\text { Company }\end{array}$ & 8 & $44.4 \%$ \\
\hline Allowed in Part & 20 & $18.7 \%$ \\
\hline Indigenous Community & 1 & $5.0 \%$ \\
\hline Municipality & 1 & $5.0 \%$ \\
\hline Grassroots Organization & 4 & $20.0 \%$ \\
\hline $\begin{array}{l}\text { Other Complaining } \\
\text { Company }\end{array}$ & 1 & $5.0 \%$ \\
\hline Natural Persons & 3 & $15.0 \%$ \\
\hline $\begin{array}{l}\text { Project Holder-Private } \\
\text { Company }\end{array}$ & 10 & $50.0 \%$ \\
\hline Rejected & 69 & $64.5 \%$ \\
\hline Indigenous Community & 7 & $10.1 \%$ \\
\hline Municipality & 1 & $1.4 \%$ \\
\hline Grassroots Organization & 4 & $5.8 \%$ \\
\hline $\begin{array}{l}\text { Socio-Environmental } \\
\text { Organization }\end{array}$ & 2 & $2.9 \%$ \\
\hline $\begin{array}{l}\text { Other Complaining } \\
\text { Company }\end{array}$ & 6 & $8.7 \%$ \\
\hline Natural Persons & 10 & $14.5 \%$ \\
\hline $\begin{array}{l}\text { Representative by Popular } \\
\text { Election }\end{array}$ & 1 & $1.4 \%$ \\
\hline $\begin{array}{l}\text { Project Holder-State } \\
\text { Company }\end{array}$ & 2 & $2.9 \%$ \\
\hline $\begin{array}{l}\text { Project Holder-Private } \\
\text { Company }\end{array}$ & 33 & $47.8 \%$ \\
\hline Project Holder-State Body & 3 & $4.3 \%$ \\
\hline Total & 106 & $100.0 \%$ \\
\hline
\end{tabular}

Source: Database compiled by the authors with data from EC 2013-2016 (references in Table 10.1).

Note: The total considers cases closed.

As for project holders, only 9 out of the 57 cases were approved by the ECs, and 38 were rejected. This means that most project holders lost at trial in ECs. However, they challenged the rejection of 14 claims, accounting for $36 \%$ of total cases. Once a cassation appeal was declared admissible by the Supreme Court, the number of successful claims doubled from 9 to 18. Therefore, it could be inferred the Supreme Court tends to accept cases brought by project holders and are likely to succeed in their appeal. 
In the organized civil society, only two claims were approved by the ECs, with 12 claims being rejected and five claims being allowed partially. Likewise, $75 \%$ of the rejected claims (9 cases) were challenged, but only one succeeded in the Supreme Court. When civil society claimants won at the ECs, these verdicts were appealed in the Supreme Court, with one of them being revoked. In total, civil society claimants won two cases and partially won another two cases. The comparison between these results and those received by project holders reveals a considerable gap: 18 successful cases against two successful cases.

\section{Conclusion}

The combination of descriptive and institutional analysis conducted throughout this study reveals that the rejection of projects resulting from non-project holders' claims before the ECs is a sporadic event.

It is likewise worth noting that, given the contentious administrative nature of this court, the only decision they can issue favoring non-project claimants is to reconsider cases from the moment that a procedural error took place. For instance, if invalidation is issued against an environmental assessment resolution, the court may order a reassessment of the project, but it may not ban the project's implementation in question. In this sense, it can be argued that neither the ECs nor the Supreme Court are institutions that allow civil society to control environmental assessment procedures. As for the Supreme Court's role, 8 out of 13 claims filed by non-project holders and rejected by the ECs were challenged by claimants, of which only two were allowed by the supreme tribunal. In practice, this resulted in two investment projects coming to a halt: the Achibueno hydroelectric plant, which was abandoned, and the salmon farms in Calcurrupe.

Much of the discussion around extractive economies' regulatory framework is guided by straightforward explanations on how state transformations intended to strengthen or weaken institutions. This chapter analyzed the design and operation of the ECs in Chile to illustrate how the performance of novel regulatory institutions can become detached from their fundamental normative values: in this case, ensuring and expanding access to environmental justice. This situation led us to propose the notion of institutional colonization to describe that the design and implementation of a regulatory institution are affected in its scope by the emergence of other orientations. Therefore, institutional colonization implies a redefinition of institutional goals in ECs, narrowing its mission.

It is important to point out that institutional colonization does not mean that social actors take total control of regulatory frameworks. Institutions do not become entirely instrumental or serve just one specific interest. As shown in this study, institutions are fields where different social interests enter into conflict, which reinforce the ideas held by institutional analysis (Powell \& DiMaggio, 1991; Boltanski, 2012). Therefore, institutions became factors that activate socio-environmental controversies and influence the power and strategies of different actors. 
In this regard, our study analyzed two different levels to describe institutional colonization: the design of the institutional framework and its factual operation. Both show how specific actors' interests permeate the institutions, moving them to decide in specific ways. At the design level, it is essential to highlight the supervision the ECs undertake on the Superintendence of the Environment. This institutional counterbalance role is fundamental when it comes to analyzing the operation of the ECs. According to the results of this study, most of the claims and successful cases are related to project holders who challenged the SE's decisions unfavorable to them.

The design of rules for filing legal claims before the ECs reveals a restrictive feature in terms of the issues that can be revised by these courts and who can access them. Related to the contents, ECs are mainly focused on existing environmental management instruments, showing a bias towards procedural rather than substantive aspects. According to some groups, the idea of expanding the powers of the ECs towards sectorial regulations is seen as an alternative in achieving institutional development, since one of their main weaknesses is the excessive formality in the handling of cases, disregarding values such as environmental quality and protection.

The focus on procedural justice implies that communities interested in access to these courts have to translate their challenges into cases of formal illegality in order to fit into the existing rules that organize the operation of ECs. This context could explain why invalidation is the most popular tool to access ECs among organized civil society. Another acknowledged institutional barrier is the lack of effective legal and technical guidance for filing claims against public services. It is also important to give attention to the fact that legal actions are taken because there is no other process to engage in, and this one involves long bureaucratic procedures and waiting times.

The powerful voices criticizing the excessive judicialization of investment projects due to socio-environmental considerations done by communities that are against them do not recognize the shallow rate of success for the civil society, environmentalist groups or indigenous communities when compared to project holders. The latter is true both at the ECs and Supreme Court. In this sense, despite all major Chilean business associations having spread the hypothesis that the continued obstruction to the construction of large projects has stifled private investment and economic growth through court proceedings, there is no evidence from the ECs to support this claim. On the contrary, use of the legal system to prevent projects from being implemented seldom accomplishes this goal, and instead merely increases the time and resources required for their construction.

In conclusion, creating new environmental institutions, such as the one designed in the Chilean environmental reform, is not necessarily enough to assume direct institutional strengthening. This depends on how instruments and procedures are planned, and more importantly, on how different actors use the institution.

Future studies may explore three research lines: first, in order to continue to test the judicialization hypothesis, to complement the study of ECs with the 
revision of socio-environmental cases issued at ordinary courts; second, the motivations and strategies deployed by relevant social actors in the ECs; and third, the content of the decisions issued by the ECs. This latter line of research would allow us to understand the type of arguments discussed in the courts and how specific substantive discussions are transformed by being addressed from formal perspectives, only to make discussions fit within the existing institutional frames. Additionally, the systematization of data on the limitations in access to information and comparisons with other Latin American experiences may shed light on the particular nature of the Chilean case and the potential use of the institutional colonization concept in other regulatory contexts.

\section{Notes}

1 This study was supported by the Fondo Nacional de Desarrollo Científico y Tecnológico (National Fund for Scientific and Technological Development), Fondecyt Iniciación, Chile, Grant No. 11160601, and it is based on the study "Derribando mitos: propuestas para mejorar el acceso a la justicia ambiental", conducted by Fundación Espacio Público with funds from the Embassy of Switzerland in Chile.

2 Sacrifice areas are places that have been historically impaired by heavy environmental damage, often through the concentration of locally unwanted land uses. Usually, these zones are located in low-income and vulnerable communities.

3 The Ministry of the Environment, the Environmental Assessment Service, and the Environment's Superintendence were established by Act No. 20417. The ECs were established by Act No. 20.600, which ordered the creation and implementation of three environmental courts in three supra-regional areas: the North, based in Antofagasta; the Center, based in Santiago; and the South, based in Valdivia.

4 All cases were individually registered and identified regardless of whether they referred to the same project or grouped for further deliberation.

5 Legal claims aim to revise administrative rules and procedures of the environmental public administration. Therefore, the ECs are in charge of determining the legality of measures taken by authorities.

6 ECs can also handle other matters: environmental damage (article 17, subparagraph 2) and authorization of provisional measures proposed by the Superintendence of the Environment (article 17, subparagraph 4). These are not analyzed in this study.

\section{References}

Altieri, M., \& Rojas, A. (1999). La tragedia ecológica del "milagro" neoliberal chileno. Persona y Sociedad, 13(1), 127-141.

Álvarez, R., García Marín, A., \& Ilabaca, S. (2017). Commodity prices shocks and poverty reduction in Chile. Serie de documentos de trabajo SDT 449. Universidad de Chile. http:// repositorio.uchile.cl/handle/2250/146333

Auty, R. M. (1993). Sustaining development in resource economies: The resource curse thesis. Routledge.

Auyero, J., \& Swistun, D. (2008). Inflamable: Estudio del sufrimiento ambiental. Paidós.

Auyero, J., \& Swistun, D. (2013). Expuestos y confundidos. Un relato etnográfico sobre sufrimiento ambiental. Íconos-Revista de Ciencias Sociales, 28, 137-152. https://doi. org/10.17141/iconos.28.2007.216

Bauer, C. (2002). Contra la corriente: Privatización, mercados de agua y el Estado en Chile. Lom Ediciones. 
Bebbington, A. (2010). Extractive industries and the stunted states: Conflict, responsibility and institutional change in the Andes. In R. Raman \& R. Lipschutz (Eds.), Corporate social responsibility: Discourses, practices and perspectives (pp. 97-115). Palgrave MacMillan.

Bermúdez, J. (2016). Fundamentos de derecho ambiental. Ediciones Universitarias de Valparaíso.

Bolados, G. P., \& Sánchez-Cuevas, A. (2017). Una ecología política feminista en construcción: El caso de las "mujeres de zonas de sacrificio en resistencia", Región de Valparaíso, Chile. Psicoperspectivas. Individuo y Sociedad, 16(2), 33-42. https://doi.org/10.5027/ psicoperspectivas-vol16-issue2-fulltext-977

Boltanski, L. (2012). Sociología y crítica social. Editorial Universidad Diego Portales.

Brunnschweiler, C. N., \& Bulte, E. H. (2008). The resource curse revisited and revised: A tale of paradoxes and red herrings. Journal of Environmental Economics and Management, 55(3), 248-264. https://doi.org/10.1016/j.jeem.2007.08.004

Buttel, F. (2003). Environmental sociology and the explanation of environmental reform. Organization and Environment, 16(3), 306-344. https://doi.org/10.1177\%2F1086026603256279

Chile Transparente. (2018). Riesgos de corrupción en concesiones mineras y otorgamiento de permisos ambientales: el caso de Chile. Informe del proyecto de minería para un desarrollo sostenible. Transparency Internacional. www.chiletransparente.cl/wp-content/files_mf/1517340532InformeMineriafull. compressed.pdf

Consejo Nacional de Innovación para el Desarrollo- CNID. (2017). Informe final. Evaluación de los conflictos socio-ambientales de proyectos de gran tamaño con foco en agua y energía para el periodo 1998 al 2015. www.cnid.cl/wp-content/uploads/2017/04/Informe-final-CNIDEvaluacio\%CC\%81n-de-Conflictos-Socioambientales-1.pdf

Cordero, L. (2010). La ruta del rediseño de la institucionalidad ambiental. In E. Aliste \& A. Urquiza (Eds.), Medio ambiente y sociedad. Conceptos, metodologías y experiencias desde las ciencias sociales y humanas (pp. 117-143). RIL Editores. http://repositorio.uchile.cl/ bitstream/handle/2250/118106/Aliste-y-Urquiza-2010-Medio-ambiente-y-sociedad. pdf?sequence $=1$

Cordero, L., Durán, V., Palacios, C., Rabi, V., \& Urquiza, A. (2017). Derribando mitos: Propuestas para mejorar el acceso a la justicia ambiental en Chile. Espacio Público.

Cortés, S., Molina, L. D. C., Burgos, S., Adaros, H., \& Ferreccio, C. (2016). Urinary metal levels in a Chilean community 31 years after the dumping of mine tailings. Journal of Health and Pollution, 6(10), 19-27. https://doi.org/10.5696/2156-9614-6-10.19

Delamaza, G., Maillet, A., \& Martínez, C. (2017). Socio-territorial conflicts in Chile: Configuration and politicization (2005-2014). European Review of Latin American and Caribbean Studies, 104, 23-46. https://doi.org/10.18352/erlacs.10173

Falleti, T., \& Riofrancos, T. (2018). Endogenous participation: Strengthening prior consultation in extractive economies. World Politics, 70(1), 86-121. https://doi.org/10.1017/ S004388711700020X

Foladori, G. (2005). Modernización ecológica, cambio tecnológico y globalización. Economía, sociedad y territorio, 5(18), 335-353. https://doi.org/10.22136/est002005308

Gerencia de Políticas Públicas y Desarrollo- SOFOFA. (2017). Catastro de proyectos de inversión. Sociedad de Fomento Fabril SOFOFA. http://app.sofofa.cl/indicadores/CPI/ Informe/CPI_2017.pdf

Guiloff, M. (2010). Reforma a la institucionalidad ambiental: un análisis desde el diseño institucional. In M. Guiloff, D. Hervé, \& R. Pérez (Eds.), Reforma a la institucionalidad ambiental: Antecedentes y fundamentos; programa de derecho y politica ambiental. Ediciones Universidad Diego Portales.

Guiloff, M. (2011). Nueva institucionalidad ambiental: hacia una regulación deliberativa. In J. Couso (Ed.), Anuario de derecho público 2011 (pp. 231-242). Ediciones Universidad Diego 
Portales. https://derecho.udp.cl/cms/wp-content/uploads/2020/06/Anuario-DerechoPublico-2011.pdf

Instituto de Derechos Humanos-INDH. (2015). Mapa de conflictos socioambientales en Chile. http://mapaconflictos.indh.cl/

Jänicke, M. (2017). Ecological modernization as global industrial revolution. Journal of Environmental Policy and Administration, 25, 1-32. https://doi.org/10.15301/ jepa.2017.25.S.1

Jänicke, M. (2020). Ecological modernization- a paradise of feasibility but no general solution. In L. Mez, L. Okamura, \& H. Weidner (Eds.), The ecological modernization capacity of Japan and Germany: Comparing nuclear energy, renewables, automobility and rare earth policy (pp. 13-23). Springer VS.

Larraín, S. (2007). El agua en Chile: Entre los derechos humanos y las reglas del mercado. Polis, Revista de la Universidad Bolivariana, 14, 1-17.

Library of the Chilean National Congress. (2010). Historia de la Ley No. 20417. Crea el ministerio, el servicio de evaluación ambiental y la superintendencia del medio ambiente. obtienearchivo. bcn.cl/obtienearchivo?id=recursoslegales/10221.3/3929/6/HL20417.pdf

Martínez, J., \& Díaz, A. (1997). Chile: The great transformation. Brookings Institution.

Mol, A. (1997). Ecological modernization: Industrial transformations and environmental reform. In M. Redclift \& G. Woodgate (Eds.), The international handbook of environmental sociology (pp. 138-149). Edward Elgar.

Mol, A., \& Sonnenfeld, D. (2014). Ecological modernization around the world: Perspectives and critical debates. Taylor and Francis.

Moraga, P. (2010). Más allá de la prevención: el principio de precaución. In E. Aliste \& A. Urquiza (Eds.), Medioambiente y sociedad. Conceptos, metodologías y experiencias desde las ciencias sociales y humanas (pp. 100-116). RIL Editores.

Moraga, P. (2012). Principio 10 y desarrollo eléctrico: participación y acceso a la justicia en miras a la implementación de tribunales especializados. Revista de Derecho de la Pontificia Universidad Católica de Valparaíso, 39, 291-317. http://doi.org/10.4067/ S0718-68512012000200011

Olavarría, M. (2003). Protected neoliberalism: Perverse institutionalization and the crisis of representation in post-dictatorship Chile. Latin American Perspectives, 30(6), 10-38. https://doi.org/10.1177/0094582X03256259

Olivares, A. (2010). El nuevo marco institucional ambiental en Chile. Revista Catalana de Dret Ambiental, 1(1), 1-23. https://doi.org/10.17345/1039

Pizarro, G. (2007). La reforma ambiental en Chile. Journal of Technology Management and Innovation, 2(2), 3-6. www.jotmi.org/index.php/GT/article/view/curr3

Plumer, M. C. (2013). Los tribunales ambientales: se completa la reforma a la institucionalidad ambiental. Anuario de Derecho Público, 297-315. derecho.udp.cl/wp-content/ uploads/2016/08/013_Plumer.pdf

Powell, W. W., \& DiMaggio, P. (1991). The new institutionalism in organizational analysis. University of Chicago Press.

Ross, M. (2015). What have we learned about the resource curse? Annual Review of Political Science, 18, 239-259.

Sachs, J. D., \& Warner, A. M. (1995). Natural resource abundance and economic growth. Working Paper 5398. National Bureau of Economic Research-NBER.

Sepúlveda, C., \& Rojas, A. (2010). Conflictos ambientales y reforma ambiental en Chile: Una oportunidad desaprovechada de aprendizaje institucional sobre participación ciudadana. Revista Ambiente y Desarrollo, 15-23. 
Tecklin, D., Bauer, C., \& Prieto, M. (2011). Making environmental law for the market: The emergence, character, and implications of Chile's environmental regime. Environmental Politics, 20(6), 879-898. https://doi.org/10.1080/09644016.2011.617172

Ulianova, O., \& Estenssoro, F. (2012). El ambientalismo chileno: La emergencia y la inserción internacional. Si Somos Americanos, 12(1), 183-214. https://doi.org/10.4067/ S0719-09482012000100008 